\title{
Teachers' Perspectives on Interactive Whiteboards as Instructional Tools in Four Jordanian Schools
}

\author{
Atef Abuhmaid \\ Middle East University, Jordan
}

\begin{abstract}
Cutting edge technologies are one of the main areas in which private schools compete so they can showcase themselves as pioneers In Jordan, as it is in other education contexts worldwide. The Interactive Whiteboard (IWB) is becoming one of the rapidly adopted educational technologies everywhere. However, while moving too fast to adopt new technologies, often decision is made without taking teachers' perceptions into account. The current study focuses on teachers' perspectives on two main aspects of the integration of IWBs in four Jordanian private schools: First, teachers' perceptions of IWBs as instructional tools, and second, the presence of various supporting factors identified by the literature for the success of integrating IWB into schools. The study used a 26-item Likert scale which was administered to 200 teachers in the participating schools. The results showed that the participating schools spend extensive efforts and resources in integrating IWBs into their contexts; however, some supporting factors for the effective implementation might have been overlooked. In addition, in contrast to what some professionals might expect and some vendors might try to promote, IWBs did not make teachers' job "easier" in terms of relieving teachers' workloads, despite their values as reported by teachers.
\end{abstract}

Keywords: Interactive whiteboard; IWB; Instructional technologies; Technology integration in education; ICT; Educational technologies in Jordan

\section{Introduction}

Educational organizations and schools are increasingly recognizing the potential of new technologies for improving educational outcomes so they are constantly searching the best pieces of technologies which can deliver that promise. Thus, schools race to "inject" new technologies in classrooms as their role in education is growing exponentially. As education is growing to become a large competitive market worldwide, private schools often conceive new technologies as means to promote themselves to the public. Recently, one of the rapidly adopted technologies by schools is the interactive whiteboard (IWB).

The first decade of the 21st century witnessed the spread of IWBs to replace one of the main characteristics of the traditional classroom which is the black/whiteboards. This technology is gaining much ground in schools as they can be used as a "traditional whiteboard, a large digital convergence facility or a highly sophisticated digital teaching hub" (Lee \& Winzenried, 2009, p.166). In addition, there has been a great deal of enthusiasm and hope that the new technology will provide classrooms with more vivid educational experiences. The enthusiasm has also been accompanied by hope that the new technology will be adopted rapidly by education systems, school principals, teachers, and students. Much of that hope counts on the 
built-in capabilities of this technology which encompass the capabilities of several other technologies including computers, the motion picture, television and audio recorders, video conferencing, access to the networked world, and the ready facility to integrate all manner of digital teaching tools (Lee \& Winzenried, 2009).

However, any technology or educational change is as good as its implementation. Considering the conditions of implementation in different schools, it might become clear that the context in which the IWB is integrated may influence teachers' beliefs regarding its potentials. Therefore, the variation of teachers' responses regarding the effectiveness of the IWB can reflect the context in which they are exposed to this technology. Furthermore, mmuch of the literature points to the key role of teachers in adopting and implementing new technologies as instructional tools (Cochran-Smith, 2004; Doyle \& Ponder, 1977; Gillingham \& Topper, 1999; Sarbib, 2002; Townsend \& Bates, 2007). Thus, it is important to shed light on teachers' perceptions of the new technology and its role in improving educational performance. So, the realization of the crucial role of teachers requires providing them with proper training, support, encouragement, and cooperation in order to implement the new technology effectively.

In Jordan, the competition in the private education sector leads schools to adopt new technologies in order to compete with other schools. New technologies are adopted and used to showcase the school as modern and its struggle to stay abreast with the rapid changes in the field. Cutting-edge technologies, such as IWB, iPad, tablet PC, and Intel classmate, are growing in numbers in schools. In this regard, a number of schools have shifted their teaching to have IWBs as a must for teachers to use in classrooms.

\section{IWB as Instructional Tool}

According to Lee and Winzenried (2009), the main thing that distinguishes the history of IWBs from its instructional technologies predecessors (e.g. overhead projector, instructional TV) is that they were developed with the teaching and learning in mind. Unlike other instructional technologies, IWBs were developed for teachers instead of the general market which was the main aspect of other technologies. That is, earlier technologies used to be developed for other fields and then attempts to follow to "import" such technologies into the educational arena. Often, this was a tough task for teachers and decision makers trying to figure out ways in which new technologies can be implemented effectively in order to enhance teaching and learning.

When IWBs are introduced into an educational context, the first aspects to protrude are usually the presentation and motivation. However, as teachers develop familiarity and mastery, they usually progress to more fundamental pedagogical issues which is the norm as they move their attention from the technology to its pedagogical use (Glover, Miller, Averis, \& Door, 2007; Kershner, Mercer, Warwick, \& Kleine, 2010). Nonetheless, the positive impact of IWBs has been reported on students' engagement, motivation, and enjoyment (Betcher \& Lee, 2009; Hodge \& Anderson, 2007; Muijs \& Reynolds, 2005; Shelly \& Vermaat, 2010). In addition, earlier research reported that the IWB can make some identifiable contributions to student's productive communication and thinking in primary school science (Kershner et al., 2010). Furthermore, Hodge and Anderson (2007) identified two main areas in which IWBs are effective in education: 
- The area of learner affect by increasing motivation and task engagement

- The nature of resource presentation and learning processes, potentially "affecting the development of thinking skills, encoding and retention of information, and interaction between students" (p.272).

Nonetheless, Torff and Tirotta (2010) claimed that the motivation-enhancing effects of IWBs are overstated. On the other hand, a large body of research points to the value of IWBs in enhancing students' motivation. Levy (2002), reported results from research in secondary schools, concluding that both teachers and learners perceived IWBs as having significant role in motivating students, focusing their attention and improving whole-class learning. In addition, a study conducted by Warwick, Mercer, Kershner, and Staarman (2010) concluded that the IWB can provide both the tool and environment which can encourage the creation of a shared dialogue space. Additionally, Kitson, Kearney, and Fletcher (2005) linked motivation and task engagement associated with IWB to the effect of multimedia and multi-sensory presentation.

Moreover, several new technologies can bring visuals into classrooms (Rief \& Heimburge, 2007); however, IWBs have the advantage of enhancing interactivity in the classroom as the touch screen allows students to interact directly with activities and exercises (Baran, 2010; Celik, 2012; Muijs \& Reynolds, 2005). IWBs are conglomeration of all previous educational technologies including: chalkboard, plain whiteboard, television, video, overhead projectors, and personal computers (Hall \& Higgins, 2005). Additionally, IWBs can enhance the delivery of presentation (Shelly \& Vermaat, 2010) and because their versatile nature, they can be used by teachers and students to undertake various functions and activities. Woolner and Schools (2010) also cited the positive impact on health issues as the poorly lightened classrooms can cause headaches, eyestrain and fatigue to some students when they stare on traditional boards, thus, the bright nature of IWBs can eliminate such problems.

Previous studies also pointed to the value of IWBs for scaffolding various learning styles and addressing diversity issues (BECTA, 2003; Bell, 2002; Glover et al., 2007). According to Cuthell (2006), IWBs are effective in scaffolding students' learning where the IWB "serves as the background proximal zone of learning." (p.262) Moreover, the 2003 BECTA report indicated that IWBs can be particularly helpful in using web-based resources in whole-class teaching (BECTA, 2003). That is, online resources can be used directly by teachers to showcase or clarify things to the whole classroom.

The 2007 BECTA Review indicated that in the UK the most used instructional technology by teachers during the period 2002-2005 was the IWBs by a significant margin (BECTA, 2007). Nevertheless, likewise the use of any other piece of technology in classrooms, the exploitation of the potentials of IWBs depends on how well they are used (Muijs \& Reynolds, 2005). Therefore, an educational system's investment in new technologies would be a waste of money and other resources if the technology is not adopted by teachers and implemented in the classroom (Abuhmaid, 2009; Bransford, Brown, \& Cocking, 2000; Hall \& Higgins, 2005).

Apparently, the positive impact of IWB on classrooms depends primarily on the way it's utilized. When implemented wisely, IWBs can enhance learning and teaching; on the other hand, when implemented poorly, there will be "very little noticeable change, which will include wasting of money and having unhappy, frustrated teachers." (Betcher \& Lee, 2009, P.14) 


\section{Factors Influencing the Adoption of New Technologies by Teachers}

There is a growing consensus that teachers are the primary agents for school change and the final arbiters of classroom practice (Cochran-Smith, 2004; Townsend \& Bates, 2007). Teachers retain a central role in deciding when and how a piece of technology is utilized in classrooms (Sabieh, 2001; Somekh \& Davis, 1997) so they are critical agents in mediating the integration of the IWB as instructional tools in classrooms (Sweeney, 2013). Thus, growing research on teachers' adoption of new technologies has examined various factors that influence teachers' overall adoption of new initiatives including technologies.

Previous research has identified several factors which can influence teachers' adoption of new technologies in teaching including: infrastructure (Hepp, Hinostroza, Laval, \& Rehbein, 2004), school leadership (Earley \& Weindling, 2004; Fink, 2005), follow-up and on-going support (Fiszer, 2004), teacher belief and attitudes (European SchoolNet, 2005; King, 2002), teacher competence (Zhao, 2003), and professional development (Fiszer, 2004; Guskey, 2000). It means that, in order to ensure the success of any technology in classrooms, such factors should be considered carefully.

New technologies are usually "dumped" in classrooms and teachers are expected to employ them properly in their teaching with the hope it will support student learning. Often, teachers are seen as merely receivers of decisions to adopt new technologies. Nevertheless, a large body of research stresses the key role of teachers in the implementation of new technologies in schools. In addition, teachers' beliefs in and their attitudes toward the new technology can impact its implementation to a large extent. Therefore, the current study tackles the issue of teachers' perspectives on IWBs as instructional tools after they have found themselves facing the new technology in classrooms.

\section{Research Questions}

The current study focused on IWBs as instructional tools in four private schools in Jordan from two main perspectives; first, teachers' perceptions of IWBs as instructional tools, and second, the presence of supporting factors for teachers' adoption of IWBs. Thus, the study will try to answer the following specific questions:

- How teachers perceive IWBs as instructional tools for teaching their subjects?

- How appropriate are the infrastructure, technical support, training, mentoring, and school principals in order to integrate IWBs in classrooms?

\section{Significance of the Study}

Many researchers have studied IWBs in schools and classrooms worldwide. The research has focused on various aspects of the technology in the learning environment of schools including motivation, attitudes, pedagogical benefits, and technical issues related to the integration of IWB in schools (Bell, 2002; Deaney, Chapman, \& Hennessy, 2009; Hennessy, Deaney, Ruthven, \& Winterbottom, 2007; Schmid, 2008; Torff \& Tirotta, 2010; Türel \& Johnson, 2012). However, after extensive research done by the researcher, there is little said about IWBs in the Jordanian 
context in general and private schools in particular. In addition, the few merely reports from a number of schools which are part of the "Discovery Schools" project in Jordan.

Additionally, the existing research on the integration of new technologies into education is mainly 'international research' coming from the developed contexts (Abuhmaid, 2009; Hall \& Higgins, 2005). However, developing countries, including Jordan, have different sets of conditions which can directly or indirectly impact their adoption of new technologies, which might not be issues of concern in developed countries. Therefore, the current research focuses on the integration of IWBs in Jordanian classrooms in order to reveal issues associated with the implementation of such technologies in this particular context which might be similar to other contexts in the developing world.

Although the context of Jordan is unique, and so each private school, some of the major issues identified in the current study are issues shared with other schools in Jordan as well as schools in other countries, particularly countries from the Middle East and North Africa (MENA). Thus, the results of the current study might be of interest to other schools in Jordan and in the MENA region which are moving towards the adopting of this technology.

\section{Methodology}

\section{Participants}

The research was conducted during the 2012-2013 schooling year and involved four private schools in Amman region. The selected schools were considered as pioneers in adopting new technologies among schools in Jordan as well as of the first schools which installed IWBs in classrooms. The four participating schools are considered to be rich with advanced facilities and high tuitions because the schools need to be financially capable in order to integrate such expensive technologies.

A total of 200 Likert scales were administered to a purposive sample from the selected schools. Table 1 shows the distribution of participating teachers in schools.

Table 1. Number of Teachers from Each School

\begin{tabular}{lrc}
\hline Schools & $\mathbf{f}$ & \% \\
\hline Alhoffaz Academy & 41 & 24.6 \\
AlAsryah Schools & 38 & 22.8 \\
AlHasad Schools & 47 & 28.1 \\
Alborj Schools & 41 & 24.6 \\
\hline Total & $\mathbf{1 6 7}$ & $\mathbf{1 0 0 . 0}$ \\
\hline
\end{tabular}

Teachers in the four schools were selected according to their utilization of IWBs in classrooms; therefore, principals' and other school members' help was valuable in the selection process. In total, 167 teachers completed the scales as shown in Table 2. More than half of participants were under 30 years of age and $62 \%$ were female teachers. 
Table 2. Demographic Profiles of the Participants $(N=167)$

\begin{tabular}{lrc}
\hline Gender & $\mathbf{f}$ & \% \\
\hline Female & 104 & 62.3 \\
Male & 63 & 37.7 \\
\hline Age Group & & \\
\hline $20-22$ & 37 & 22.2 \\
$26-30$ & 52 & 31.1 \\
$31-35$ & 25 & 15.0 \\
$36-45$ & 42 & 25.1 \\
46 and above & 11 & 6.6 \\
\hline Total & $\mathbf{1 6 7}$ & $\mathbf{1 0 0 . 0}$ \\
\hline
\end{tabular}

\section{Procedures}

The current study used quantitative descriptive method, in which, information is gathered and analyzed for describing situations, events or existing phenomena to identify problems and make evaluation (Ariola, 2006) based on the data we have (Schreiber \& Asner-Self, 2011). The aim of employing this method was to capture and interpret the participants' understanding of the issue in hand (Gall, Gall, \& Borg, 2007). In order to minimize the bias of self-reporting, participants were not asked to identify themselves in any way. A Likert scale was developed for the current study to gather data from participating teachers in respect to their experiences with IWBs in schools.

\section{Data Collection and Analysis}

In order to create a scale consistent with the study's purpose, related literature was examined including instructional theories and strategies, current practices, problems and perceptions of IWB users (Beauchamp \& Parkinson, 2005; Betcher \& Lee, 2009; Hall \& Higgins, 2005; Jordan Education Initiative, 2009a, 2009b; Kitson et al., 2005; Levy, 2002; Miller \& Glover, 2010; Moss \& Jewitt, 2010; Smith, Higgins, Wall, \& Miller, 2005; Türel \& Johnson, 2012; Warwick et al., 2010). In order to get feedback on the items, the scale was distributed to 7 teachers who were active IWB users across various subject areas. Obtaining teachers' opinions on the scale items shaped its final version as revisions were made based on these opinions. This step was vital to achieve a comprehensible and relevant scale in terms of face and content validity (Black \& Champion, 1976).

The initial scale contained 28 items. However, 2 items were deleted after running preliminary Cronbach's Alpha for internal consistency. Therefore, the final version of the scale contained 26 items, and it was believed that the scale has a high degree of internal consistency as the Cronbach's alpha for the scale was .93. The scale items focused on the two main research questions. Thus, the scale included questions related to teachers' perspectives on IWBs as instructional tools and about the presence of other supporting factors to the successful integration of IWBs. The supporting factors included: teacher training on IWBs implementation in classrooms, school preparedness for utilizing IWBs, and support from school principals, 
mentors and technicians they receive for their utilization of this technology. The scale was delivered in Arabic as it is the participants' native language.

In the data analysis process descriptive statistical analysis was employed to make sense of the data collected. Cross-tabulation was used to present the means and standard deviations in each table.

\section{Results}

\section{Teachers' Perspective on IWBs as Instructional Tools}

This section presents findings related to the first research question: "How do teachers perceive IWBs as educational tools for teaching subjects?"

As stated previously, the first research question of the study focused on teachers' perception of IWBs as instructional tools. The average mean of the 15 items in this category to all schools was high ( $M=4.3$ ). Table 3 shows a strong consent among teachers to the statement "The use of interactive whiteboards provides resources which enrich my teaching subject" $(M=4.4)$. In addition, teachers acknowledged the potential of the IWB to "motivate students' learning" $(M=4.5)$ which might be due to the "variety of resources for teaching" $(M=4.3)$ which the IWB brings into the classroom. Furthermore, teachers believed in potentials of the IWBS in enriching subject areas "with the multimedia resources" ( $M=4.2)$.

Noticeably, Alhofaz Academy scored the least among all other schools $(M=3.9)$ in this category which can be linked to the school's new experience with the IWB as it was in its first year of implementation. Thus, the use of IWB had not settled yet. In addition, teachers were less optimistic about the role of the IWB in "relieving their loads as teachers" $(M=4.0)$. Nevertheless, more teachers reported that the use of interactive whiteboard saves time and efforts during teaching ( $M=4.3$ for each item). In addition, the item stating "I believe that the interactive whiteboard is effective in teaching my subject" scored the least among male and female teachers $(M=3.7)$ even in Alasryah school, which had the highest score among all schools $(M=4.6)$, this item scored the least $(M=4.3)$.

Overall, Alasryah school scored the highest in this category $(M=4.6)$ and Alhofaz school was the least $(M=3.9)$. Moreover, most teachers responded positively to the item "I believe that my experience with the interactive whiteboard in teaching my subject is excellent" $(M=4.5)$ reflecting their positive experience with the technology.

\section{Supporting Teachers' Integration of IWBs in Classrooms}

This section presents findings related to the second research question which focused on the appropriateness of certain factors identified in the literature as influential on teachers' adoption of the IWB as an instructional tool. The related research question was: "How appropriate are the infrastructure, technical support, training, mentoring, and school principals in order to integrate IWBs in classrooms?" 
Table 3. Means and Standard Deviations of Teachers' Perceptions of IWBs as Instructional Tools ( $\mathrm{HO}=$ Alhofaz, $\mathrm{AS}=$ Alasryah, $\mathrm{HA}=$ Alhasad, $\mathrm{BO}=$ Alborj), $\mu=$ Average)

\begin{tabular}{|c|c|c|c|c|c|c|c|c|}
\hline \multirow[t]{2}{*}{ Item } & \multicolumn{4}{|c|}{$\begin{array}{l}\text { Mean } \\
\text { (schools) }\end{array}$} & \multicolumn{3}{|c|}{ Gender } & \multirow[b]{2}{*}{ SD } \\
\hline & $\mathrm{HO}$ & AS & HA & BO & $\begin{array}{l}\mu \\
M\end{array}$ & $\mathbf{M}$ & $\mathbf{F}$ & \\
\hline $\begin{array}{l}\text { The use of interactive whiteboards helps in providing a } \\
\text { variety of resources for teaching }\end{array}$ & 4.1 & 4.8 & 4.6 & 4.6 & 4.5 & 4.5 & 5 & 0.63 \\
\hline $\begin{array}{l}\text { I believe that the interactive whiteboard is effective in } \\
\text { teaching my subject }\end{array}$ & 4.0 & 4.8 & 4.6 & 4.3 & 4.4 & 4.6 & 4 & 0.80 \\
\hline $\begin{array}{l}\text { The use of interactive whiteboards provides resources } \\
\text { which enrich my teaching subject }\end{array}$ & 4.0 & 4.7 & 4.6 & 4.5 & 4.5 & 4.4 & 4 & 0.71 \\
\hline $\begin{array}{l}\text { I think that the interactive whiteboard enriches my subject } \\
\text { with the multimedia resources }\end{array}$ & 3.9 & 4.7 & 4.7 & 4.4 & 4.4 & 4.5 & 4 & 0.83 \\
\hline $\begin{array}{l}\text { The use of interactive whiteboard in teaching grabs } \\
\text { students' attention }\end{array}$ & 4.0 & 4.7 & 4.5 & 4.5 & 4.4 & 4.5 & 4 & 0.67 \\
\hline $\begin{array}{l}\text { The use of interactive whiteboard encourages students to } \\
\text { learn }\end{array}$ & 4.0 & 4.6 & 4.4 & 4.6 & 4.4 & 4.2 & 5 & 0.67 \\
\hline $\begin{array}{l}\text { The use of interactive whiteboard motivates students' } \\
\text { learning }\end{array}$ & 4.0 & 4.7 & 4.4 & 4.5 & 4.4 & 4.4 & 4 & 0.73 \\
\hline $\begin{array}{l}\text { I believe that my experience with the interactive whiteboarc } \\
\text { in teaching my subject is excellent }\end{array}$ & 4.0 & 4.7 & 4.5 & 4.5 & 4.4 & 4.5 & 4.3 & 0.69 \\
\hline $\begin{array}{l}\text { The use of interactive whiteboard improves interactivity in } \\
\text { classrooms }\end{array}$ & 4.0 & 4.7 & 4.4 & 4.5 & 4.4 & 4.3 & 4.4 & 0.75 \\
\hline The interactive whiteboard improves students' retention & 4.1 & 4.6 & 4.3 & 4.4 & 4.4 & 4.3 & 4 & 0.73 \\
\hline $\begin{array}{l}\text { I think that the use of interactive whiteboard provides } \\
\text { flexibility which helps in more focus on the contents }\end{array}$ & 3.8 & 4.7 & 4.6 & 4.2 & 4.3 & 4.5 & 4 & 0.88 \\
\hline $\begin{array}{l}\text { I feel that using the interactive whiteboard is reflected } \\
\text { positively on students' achievement }\end{array}$ & 3.6 & 4.6 & 4.6 & 4.1 & 4.2 & 4.1 & 4 & 0.86 \\
\hline $\begin{array}{l}\text { The use of interactive whiteboard saves time during } \\
\text { teaching }\end{array}$ & 3.7 & 4.6 & 4.3 & 4.2 & 4.2 & 4.2 & 4.2 & 0.99 \\
\hline $\begin{array}{l}\text { The use of interactive whiteboard relieves my load as a } \\
\text { teacher }\end{array}$ & 3.7 & 4.5 & 4.1 & 4.0 & 4.1 & 4.3 & 4.0 & 1.08 \\
\hline $\begin{array}{l}\text { The use of interactive whiteboard saves efforts during } \\
\text { teaching }\end{array}$ & 4.0 & 4.4 & 4.0 & 3.9 & 4.1 & 4.2 & 4.0 & 1.07 \\
\hline Average & 3.9 & 4.7 & 4.4 & 4.3 & 4.3 & 4.2 & 4.3 & .632 \\
\hline
\end{tabular}

Table (4) shows that the average mean for all items in this category was slightly less $(M=4.2)$ than the average mean of the items related to their beliefs in the tool as an instructional tool $(M=4.3)$. As the infrastructure is concerned, the highest mean in this category was to the item stating "It is easy to access and use interactive whiteboard in my school" and "The interactive whiteboard is located in a proper place in my school" ( $M=4.7$ and $M=4.4$ respectively) which was shared by the majority of teachers in all schools. That is, IWBs were available in most classrooms, which is the highest mean among all survey items. In addition, teachers were positive about the adequacy of school infrastructure to use IWBs $(M=4.3)$. 


\section{Technical support}

Teachers expressed low satisfaction with the technical support they receive during their IWB implementation. Teachers responded with less satisfaction to the item stating: "I receive proper technical support during the use of interactive whiteboards" $(M=3.9)$ and to the item "The computer lab coordinator provides help when needed" $(M=3.8)$ which were of the least among all items and male teachers scored less than females in for both items $(M=3.3$ and $M=3.5$ respectively).

\section{Training}

Table 4 shows that there was an overall satisfaction among teachers regarding the training they had received on using IWBs $(M=4.4)$ to the item "I received proper training on using Interactive Whiteboards" which was above the average mean for this category $(M=4.2)$. However, when teachers were asked whether the training was enough for them to use IWBs effectively in teaching subjects, they were not as satisfied $(M=3.7)$ which is the least average mean of all survey items.

Both Alhofaz Academy and Alborj School scored low in regard to teachers' satisfaction with the training on integrating IWBs in teaching subjects. Alborj School reported low satisfaction $(M=3.0)$ which is significantly below the average mean for both this category and the average for all survey items. In addition, male teachers gain were less satisfied with the training than females ( $M=3.4$ and $M=4.0$ respectively).

\section{Mentoring}

There was a mixed feeling about mentors and their essential role in the implementation of IWB by teachers. The mean for the item "The mentor encourages me to use interactive whiteboards in teaching my subject" was $(M=4.3)$ which is above the average mean of this category and the average for all survey items. However, teachers were significantly less confident regarding their mentors' knowledge to guide them while using the IWB ( $M=3.8$ ) which is significantly below the average mean for items in this category $(M=4.2)$.

\section{School Principals}

Teachers were relatively satisfied with the principals' role in facilitating IWBs implementation. Table 4 shows that teachers were positive about their principals' cooperation and facilitating their utilization of the IWBs in teaching ( $M=4.3$ for each item). Once again, female teachers from all schools were more positive about the principals' support.

Overall, Alasryah School scored the highest in this category $(M=4.5)$ and Alhofaz school was the least $(M=3.9)$. This can be linked to the individual status and experience of each school; Alasryah School was in its $18^{\text {th }}$ year and Alhofaz School was only one year old. In addition, female teachers scored slightly higher for this category compared with male teachers $(M=4.0$ and $\mathrm{M}=4.2$ respectively). 
Table 4. Means and Standard Deviation (SD) of Items Related to Q2 (HO=Alhofaz, AS=Alasryah, $\mathrm{HA}=$ Alhasad, $\mathrm{BO}=\mathrm{Alborj}$ ), $\mu=$ Average

\begin{tabular}{|c|c|c|c|c|c|c|c|c|}
\hline \multirow[t]{2}{*}{ Item } & \multirow{2}{*}{$\begin{array}{l}\mathrm{M} \\
\mathrm{HO}\end{array}$} & \multicolumn{4}{|c|}{ Schools } & \multicolumn{2}{|c|}{ Gender } & \multirow[t]{2}{*}{ SD } \\
\hline & & AS & HA & BO & $\begin{array}{l}\mu \\
M\end{array}$ & $M$ & $\mathbf{F}$ & \\
\hline $\begin{array}{l}\text { It is easy to access and use interactive whiteboard } \\
\text { in my school }\end{array}$ & 4.4 & 4.8 & 4.7 & 4.9 & 4.7 & 4.6 & 4.8 & 0.99 \\
\hline $\begin{array}{l}\text { The interactive whiteboard is located in a proper } \\
\text { place in my school (lighting, seats, ventilation ...) }\end{array}$ & 4.2 & 4.4 & 4.2 & 4.6 & 4.4 & 4.1 & 4.5 & 0.46 \\
\hline $\begin{array}{l}\text { I received proper training on using Interactive } \\
\text { Whiteboards }\end{array}$ & 4 & 5 & 4 & 5 & 4.5 & 4.2 & 4.4 & 0.78 \\
\hline $\begin{array}{l}\text { We have adequate infrastructure for using } \\
\text { interactive whiteboard }\end{array}$ & 4 & 4.5 & 4.2 & 4.6 & 4.3 & 4.2 & 4.4 & 1.14 \\
\hline $\begin{array}{l}\text { The school leadership is cooperative with me to } \\
\text { use interactive whiteboards during teaching }\end{array}$ & 4 & 4.5 & 4 & 4.7 & 4.3 & 4.1 & 4.4 & 1.12 \\
\hline $\begin{array}{l}\text { The school principal facilitates the use of } \\
\text { interactive whiteboards in teaching }\end{array}$ & 4.2 & 4.4 & 4 & 4.7 & 4.3 & 4.1 & 4.5 & 0.77 \\
\hline $\begin{array}{l}\text { I receive proper technical support during the use } \\
\text { of interactive whiteboards }\end{array}$ & 3.6 & 4.5 & 3.7 & 3.6 & 3.9 & 3.3 & 4.2 & 1.05 \\
\hline $\begin{array}{l}\text { The computer lab coordinator provides help when } \\
\text { needed }\end{array}$ & 3.3 & 4.5 & 3.7 & 3.7 & 3.8 & 3.5 & 4 & 0.74 \\
\hline $\begin{array}{l}\text { The mentor encourages me to use interactive } \\
\text { whiteboards in teaching my subject }\end{array}$ & 4.1 & 4.4 & 4.5 & 4 & 4.3 & 4.1 & 4.4 & 0.78 \\
\hline $\begin{array}{l}\text { I think the mentor has enough knowledge to guide } \\
\text { me while using the interactive whiteboard }\end{array}$ & 3.7 & 3.8 & 3.7 & 3.9 & 3.8 & 3.9 & 3.7 & 0.69 \\
\hline $\begin{array}{l}\text { I received adequate training on using Interactive } \\
\text { Whiteboards }\end{array}$ & 4.4 & 4.6 & 4.3 & 4.1 & 4.4 & 4 & 5 & .730 \\
\hline $\begin{array}{l}\text { The training was enough for me to use Interactive } \\
\text { whiteboards effectively in teaching my subject }\end{array}$ & 3.5 & 4.4 & 4 & 3 & 3.7 & 3.4 & 4 & 0.69 \\
\hline Average & 3.9 & 4.5 & 4.1 & 4.2 & 4.2 & 4 & 4.2 & .83 \\
\hline
\end{tabular}

\section{Discussion}

In order to capture teachers' perspectives on the integration of IWBs in four private Jordanian schools, a Likert scale was administered. As the results of the study showed, IWBs were indeed in place in these school with teachers expressing satisfaction with its presence, however, previous studies stressed that the provision of a new technology is only a "prerequisite", rather than the goal, of the long process of integrating it in education (Byrom, 2001; Dimmock, 2000; Downes et al., 2001; Granger, Morbey, Lotherington, Owston, \& Wideman, 2002; Hakkarainen et al., 2001; Hepp et al., 2004). Therefore, while excessive efforts and resources are dedicated to the provision of new technology, some other supporting factors for the successful implementation of technology might be overlooked by schools overemphasizing the technology itself rather than its effective utilization. 
Understandably, "dumping" technology on teachers with much hope that it will bear fruit and improve education has proven to be a wishful thinking (Lee \& Winzenried, 2009). Teacher training and professional development are closely linked to improving learning outcomes and school environment (Celik, 2012; Mouzakis \& Bourletidis, 2010). In the current study, teachers acknowledged receiving training on using IWBs; however, they believed that the training was not enough for them to exploit the potentials of IWBs in teaching their subjects. This point can be linked to the demand made by teachers for more training. Usually, teachers receive initial training on using IWB's features which is important for them to deal with the technology. Nevertheless, training needs to go to higher level in order to help teachers to make sense of the technology in regard to the subject matter. The training should focus on the potentials of IWBs for each subject. Furthermore, this can stress the role of mentors in helping teachers for the implementation in subjects.

The fundamental role of mentors in the integration of new technologies in classrooms is often underestimated. In the current study, teachers reported receiving encouragement from their mentors on using IWBs; however, teachers also reported that mentors did not have the knowledge to assist them to integrate IWBs in teaching subjects. The role of mentors is important especially when teachers try to integrated new technologies into their teaching subjects (Abuhmaid, 2009). That is, the initial stage of teachers' attempts to adopt new technologies can be crucial in their decisions whether to adopt or not. Therefore, mentors can help teachers in "making sense" of the theoretical knowledge they have about a new piece of technology by interconnecting it with their own practices in classrooms. In this regard, mentors can foster and nurture teachers' progression with IWBs from the technology itself to its pedagogical implementation.

Furthermore, the provision of new technology has to go side by side with training teachers on using it for the benefits of teaching subjects as competence leads to confidence. Therefore, teachers need to have confidence that they have the required skills for them to master IWBs as instructional tools. Once teachers gain confidence, they might start changes in their teaching strategies and methods; otherwise, they might remain reluctant to explore their potentials in classrooms. An important aspect of training should be helping teachers to link the new knowledge they receive with their own teaching. That is, teachers need to know exactly how the new technology might be implemented in their own contexts.

Furthermore, the results of the current study clearly showed that in contrast to what some professionals might expect, and some vendors might try to promote, IWBs should not be expected to make teachers' job "easier" in the sense of less time and efforts needed for the preparation for teaching. On contrary, the effective implementation of IWBs requires more efforts and time for preparation which supports earlier findings that teachers' profession does not necessarily become easier by integrating new technologies (Abuhmaid, 2009, 2011; Dwyer, Ringstaff, \& Sandholtz, 1991). However, the present study pointed to a fact that the built-in features of IWBs can save time "during" teaching. The integration of new technologies in education requires additional time and efforts from teachers in order to achieve high quality instructional performance. That is, teachers need to locate resources and have their lessons well-prepared beforehand requiring them to search, organize, and make sure the technology is working properly adding to their burden. Accordingly, the easiness of IWBs feature should not be promoted to teachers as it might have negative impact when teachers embrace IWBs which turns out to be in contrast to what they believed initially which might result in the abandonment of IWBs. Therefore, the emphasis should be placed on the quality that IWBS bring into the classroom through features like interactivity and breaking classroom routine and 
students' engagement and the interactive media that the IWBs can bring into classrooms (Beauchamp \& Parkinson, 2005; Betcher \& Lee, 2009; Jordan Education Initiative, 2009a; Warwick et al., 2010). However, this feature of IWBs should not be underestimated while promoting IWBs as research has indicated that the most important factor which can increase teachers' positive attitude towards new technologies is the belief that they can improve the students' achievement (Downes et al., 2001; Subhi, 1999). So, it is not the ease of use or the money incentives, despite their importance, what make teachers adopt a new technology; rather, it is the value of it and its benefit for student learning (Bahr, Shaha, Farnsworth, Lewis, \& Benson, 2004; Billeh, 2002; European SchoolNet, 2005; Gilmore, 1995; Hu, Clark, \& Ma, 2003).

Furthermore, technical assistance is also vital for the successful implementation of a new technology in schools and can be a significant predictor of its adoption by teachers (Fullan, 2007). Thus, as the study showed, teachers had a relatively low satisfaction with the technical support they receive when they try to use IWB which can influence their overall attitudes and adoption of the new technology as the unreliable technologies is found to be "the best innovation killer" (Hepp et al., 2004, p.35). So, if the effort is focused on the initial installation of IWBs, which is done by the vendor or the merchandise, without giving the same attention to the working conditions of the technology and the technical support provided can lead to its abandonment by teachers.

Teachers have more courage to try new technologies when they are easily accessed. Teachers in the current study had advantage by having IWBs available in classrooms which reflects a high degree of availability of IWBs in schools. In Levy's (2002) study, teachers reported that their motivation to use IWBs depended to a large extent on the ease and frequent access to IWBs rooms for teaching and they were less likely to explore their possibilities in teaching when the use of IWBs needed pre-booking to. Therefore, participating schools in the current study had the foundation for successful integration of IWBs which gives them the advantage for moving forward in the successful integration of this technology.

\section{Conclusion}

It is neither the hardware nor the software what makes quality learning; rather, it is the quality teaching. Despite the fact that software and hardware are increasingly becoming indispensable for education, they do not improve it by simply "dumping" technology in classrooms. Certainly, IWBs are powerful tools which can be utilized by teachers and students in order to enhance teaching and learning. However, like all their other educational technologies predecessors, IWBs should not be integrated within educational contexts without being envisioned in the lens of instructional design and the systemic approach in order to align their integration with the intended educational outcomes.

As the current study illustrated, teachers have belief in the potential of IWBs as instructional tools to powerfully enhance educational outcomes. Nonetheless, as schools are still experimenting with the use of IWBs in teaching, it is important not to overlook other supporting factors for their effective implementation. The current study identified several factors including teacher training, follow up and support, school principals, adequate infrastructure, and mentoring, which are believed to be supporting factors for the effective utilization of IWBs by teachers in order to improve educational performance. 
Based on the discussion and findings of the study, schools are encouraged to share their thoughts about adopting new technologies with teachers. School leadership can facilitate teachers' adoption of a new piece of technology by sharing the vision of the school with teachers and providing them with adequate training to better utilize the technology in the classroom. Furthermore, support and follow-up for teachers is needed throughout the process of implementation. Furthermore, research is needed to determine how IWB use is associated with academic performance, as well as to examine how teachers use IWB for educational purposes. In addition, further investigation is needed to explore the effectiveness of IWBs in teaching specific subject areas.

\section{References}

Abuhmaid, A. (2009). ICT integration across education systems: The experience of Jordan in educational reform. Saarbrücken, Germany: VDM Verlag Dr. Müller.

Abuhmaid, A. (2011). Embracing ICT by the Jordanian education system. In F. Albadri \& S. Abdullah (Eds.), Cases on ICT acceptance, investment and organization: Cultural practices and values in the Arab world. Hershey, PA: IGI Global.

Ariola, M. (2006). Principles and methods of research. Manilla: Rex Book Store.

Bahr, D. L., Shaha, S. H., Farnsworth, B., Lewis, V. K., \& Benson, L. F. (2004). Preparing tomorrow's teachers to use technology: Attitudinal impacts of technology-supported field experience on pre-service teacher candidates. Journal of Instructional Psychology, 31(2), 88-97.

Baran, B. (2010). Experiences from the process of designing lessons with interactive whiteboard: ASSURE as a road map. Contemporary Educational Technology, 1(4), 367380 .

Beauchamp, G. \& Parkinson, J. (2005). Beyond the 'wow' factor: Developing interactivity with the interactive whiteboard. School Science Review, 86(3), 97-103.

BECTA. (2003). What the research says about interactive whiteboards. Retrieved on 27 September 2008 from http://www.hpedsb.on.ca/ec/services/cst/elementary/math/ documents/whiteboards_research.pdf

BECTA. (2007). Harnessing technology review 2007: Progress and impact of technology in education: Summary report. Retrieved on 29 September 2009 from http://dera.ioe. ac.uk/1426/1/becta_2007_htreview_summary.pdf

Bell, M. A. (2002). Why use an interactive whiteboard? A Baker's dozen reasons! Retrieved on 27 September 2008 from http://teachers.net/gazette/JAN02/mabell.html

Betcher, C. \& Lee, M. (2009). The interactive whiteboard revolution : Teaching with IWBs. Camberwell, Australia: Australian Council for Educational Research Press.

Billeh, V. (2002). Educational reform in the Arab region. Retrieved on 17 June 2007 from http://www.erf.org.eg/nletter/Newsletter_Sum02/NewsletterSumlssue.Q30-32.pdf

Bransford, J. D., Brown, A. L., \& Cocking, R. R. (Eds.). (2000). How people learn: Brain, mind, experience and schools. Washington, DC: National Academy Press. 
Byrom, E. (2001). Factors influencing the effective use of technology for teaching and learning. Retrieved on 11 January, 2008 from http://www.serve.org/seir-tec/publications/lessons. pdf

Celik, S. (2012). Competency levels of teachers in using interactive whiteboards. Contemporary Educational Technology, 3(2), 115-129.

Cochran-Smith, M. (2004). Taking stock in 2004: Teacher education in dangerous times. Journal of Teacher Education, 55(1), 3-7.

Cuthell, J. P. (2006). Ms. Chips and her battle against the cyborgs: Embedding ICT in professional praxis. In E. K.Sorensen, D. Ó. Murchú \&G. Ó.Doghair (Eds.), Enhancing learning through technology. London: Information Science.

Deaney, R., Chapman, A., \& Hennessy, S. (2009). A case-study of one teacher's use of an interactive whiteboard system to support knowledge co-construction in the history classroom. The Curriculum Journal, 20(4), 365-387.

Dimmock, C. (2000). Designing the learning-centred school, a cross-cultural perspective. New York: Falmer.

Downes, T., Fluck, A., Gibbons, P., Leonard, R., Matthews, C., Oliver, R., Margaret Vickers \& Williams, M. (2001). Making better connections: Models of teacher professional development for the integration of information and communication technology into classroom practice. Retrieved on 11 January 2008 from http://www.dest.gov.au/ schools/ Publications/2002/MBC.pdf

Doyle, W. \& Ponder, G. A. (1977). The practicality ethic in teacher decision-making. Interchange, 8(3), 1-12.

Dwyer, D. C., Ringstaff, C., \& Sandholtz, J. (1991). Changes in Teachers' Beliefs and Practices in Technology-Rich Classrooms. Educational Leadership, 8(48), 45-52.

Earley, P. \& Weindling, D. (2004). Understanding school leadership. London: Paul Chapman.

European SchoolNet. (2005). Assessment schemes for teachers' ict competence- A policy analysis. Retrieved on 19 February 2010 from http://www-old.eun.org/insight-pdf/ special_reports/PIC_Report_Assessment\%20schemes_insightn.pdf

Fink, D. (2005). Developing leaders for their future not our past. In M. J. Coles \& G. Southworth (Eds.), Developing leadership: Creating the schools of tomorrow. Maidenhead: England: McGraw-Hill Education.

Fiszer, E. P. (2004). How teachers learn best: An ongoing professional development model. Maryland: ScarecrowEducation.

Fullan, M. (2007). The NEW meaning of educational change (4th ed.). New York: Teachers College.

Gall, M. D., Gall, J. P., \& Borg, W. R. (2007). Educational research: An introduction (8th ed.). Boston: Pearson.

Gillingham, M. G. \& Topper, A. (1999). Technology in teacher preparation: Preparing teachers for the future. Journal of Technology and Teacher Education, 7(4), 303-321.

Gilmore, A. M. (1995). Turning teachers on to computers: Evaluation of a teacher development program. Journal of Research on Computing in Education, 27(3), 251-269. 
Glover, D., Miller, D., Averis, D., \& Door, V. (2007). The evolution of an effective pedagogy for teachers using the interactive whiteboard in mathematics and modern languages: An empirical analysis from the secondary sector. Learning, Media and Technology, 32(1), 520.

Granger, C. A., Morbey, M. L., Lotherington, H., Owston, R. D., \& Wideman, H. H. (2002). Factors contributing to teachers' successful implementation of IT. Journal of Computer Assisted Learning, 18(4), 480-488.

Guskey, T. R. (2000). Evaluating professional development. California: Crown Press.

Hakkarainen, K., Muukonen, H., Lipponen, L., Ilomaki, L., Rahikainen, M., \& Lehtinen, E. (2001). Teachers' information and communication technology (ICT) skills and practices of using ICT. Journal of Technology and Teacher Education, 9(2), 181-197.

Hall, I. \& Higgins, S. (2005). Primary school students' perceptions of interactive whiteboards. Journal of Computer Assisted Learning, 21, 102-117.

Hennessy, S., Deaney, R., Ruthven, K., \& Winterbottom, M. (2007). Pedagogical strategies for using the interactive whiteboard to foster learner participation in school science. Learning, Media and Technology, 32, 283-301

Hepp, P., Hinostroza, E., Laval, E., \& Rehbein, L. (2004). Technology in schools: Education, ICT and the knowledge society. Retrieved on 2 October 2013 from http://www-wds. worldbank.org/external/default/WDSContentServer/WDSP/IB/2005/01/10/000160016_ 20050110162933/Rendered/PDF/311940PAPEROEd110ICTOoct0401public1.pdf

Hodge, S. \& Anderson, B. (2007). Teaching and learning with an interactive whiteboard: a teacher's journey. Learning, Media and Technology, 32(3), 271-282.

Hu, P. J. H., Clark, T. H. K., \& Ma, W. W. (2003). Examining technology acceptance by school teachers: A longitudinal study. Information \& Management, 41(3), 227-241.

Jordan Education Initiative. (2009a). KETAB interactive whiteboards in the discovery schools. Amman, Jordan. Retrieved on 5 September 2013 from http://www.jei.org.jo/cms/sites/ default/files/reports/3.\%20KETAB\%20Interactive\%20White\%20Boards.pdf

Jordan Education Initiative. (2009b). SMART interactive whiteboards in the discovery schools Amman, Jordan.Retrieved on 15 September 2013 from http://www.jei.org.jo/cms/ sites/default/files/reports/SMART\%20Interactive\%20White\%20Boards.pdf

Kershner, R., Mercer, N., Warwick, P., \& Kleine, J. S. (2010). Can the interactive whiteboard support young children's collaborative communication and thinking in classroom science activities? International Journal of Computer-Supported Collaborative Learning, 5(4), 359-383.

King, K. P. (2002). Technology, science teaching, and literacy: A century of growth. New York: Kluwer Academic.

Kitson, L., Kearney, J., \& Fletcher, M. (2005, July). Transversing the digital divide using interactive whiteboards. Paper presented at the Australian Teacher Education Association's 33rd Annual Conference. Gold Coast, Queensland, Australia.

Lee, M. \& Winzenried, A. (2009). The use of instructional technology in schools: Lessons to be learned. Camberwell, Victoria, Australia: ACER Press. 
Levy, P. (2002). Interactive whiteboards in learning and teaching in two Sheffield schools: A developmental study. Retrieved on 20 September 2010 from http://dis.shef.ac.uk /eirg/projects/wboards.htm

Miller, D. \& Glover, D. (2010). Interactive Whiteboards: A Literature Survey. In M. Thomas \& E. C. Schmid (Eds.), Interactive whiteboards for education: Theory, research and practice (pp. 1-19). Hershey, New York: IGI Global.

Moss, G. \& Jewitt, C. (2010). Policy, pedagogy and interactive whiteboards: What lessons can be learnt from early adoption in England? In M. Thomas \& E. C. Schmid (Eds.), Interactive whiteboards for education: Theory, research and practice (pp. 20-36). Hershey, PA: IGI Global.

Mouzakis, C. \& Bourletidis, C. (2010). A blended learning course for teachers' ongoing professional development in Greece. In J. Yamamoto, J. C. Kush, R. Lombard \& C. J. Hertzog (Eds.), Technology implementation and teacher education: Reflective models (pp. 1-24). Hershey, PA: IGI Global.

Muijs, D. \& Reynolds, D. (2005). Effective teaching: Evidence and practice (2nd ed.). London: Sage.

Rief, S. F. \& Heimburge, J. A. (2007). How to reach and teach all children through balanced literacy? San Francisco: Jossey-Bass.

Sabieh, C. (2001, March). A confident Arab scholar: Faculty development and technology. Paper presented at the use of information technology in higher education in arab universities conference. Beirut, Lebanon.

Sarbib, L. (2002). Building knowledge societies in the Middle East and North Africa. Retrieved on 18 September 2010 from http://www.worldbank.org/k4dmarseille

Schmid, E. C. (2008). Potential pedagogical benefits and drawbacks of multimedia use in the English language classroom equipped with interactive whiteboard technology. Computers \& Education, 51(4), 1553-1568.

Schreiber, J. B. \& Asner-Self, K. (2011). Educational research: The Interrelationship of questions, sampling, design, and analysis. Hoboken, NJ: Wiley \& Sons.

Shelly, G. B. \& Vermaat, M. E. (2010). Discovering computers 2010: Living in a digital world, Introductory. Boston: Course Technology, Cengage Learning.

Smith, H. J., Higgins, S., Wall, K., \& Miller, J. (2005). Interactive whiteboards: Boon or bandwagon? A critical review of the literature. Journal of Computer Assisted Learning, 21(2), 91-101.

Somekh, B. \& Davis, N. (Eds.). (1997). Using information technology effectively in teaching and learning. London: Routledge.

Subhi, T. (1999). Attitudes toward computers of gifted students and their teachers. High Ability Studies, 10(1), 69-84.

Sweeney, T. (2013). Understanding the use of interactive whiteboards in primary science. Australasian Journal of Educational Technology, 29(2), 217-232.

Torff, B. \& Tirotta, R. (2010). Interactive whiteboards produce small gains in elementary students' self-reported motivation in mathematics. Computers \& Education, 54(2010), 379-383. 
Townsend, T. \& Bates, R. (2007). Teacher education in a new millennium: Pressures and possibilities. In T. Townsend \& R. Bates (Eds.), Handbook of teacher education: Globalization, standards and professionalism in times of change (pp.3-24). Dordercht, The Netherlands: Springer.

Türel, Y. K. \& Johnson, T. E. (2012). Teachers' belief and use of interactive whiteboards for teaching and learning. Educational Technology \& Society, 15(1), 381-394.

Warwick, P., Mercer, N., Kershner, R., \& Staarman, J. K. (2010). In the mind and in the technology: The vicarious presence of the teacher in pupil's learning of science in collaborative group activity at the interactive whiteboard. Computers \& Education, 55(1), 350-362.

Woolner, P. \& Schools, F. (2010). The design of learning spaces. London: Continuum.

Zhao, Y. (2003). What teachers need to know about technology: Framing the question. In Y. Zhao (Ed.), What should teachers know about technology: Perspectives and practices. Greenwich: Information Age.

Correspondence: Atef Abuhmaid, Ph.D., Educational Technology, Faculty of Educational Sciences, Middle East University, Jordan 